\title{
Bir Tartım Otomasyonunda, Platform Tipi Yük Hücrelerinin, S-tipi Olarak Kullanılması
}

\author{
Ebubekir Yaşar $^{1 *}$ \\ 1* Tokat Gaziosmanpaşa Üniversitesi, Mühendislik ve Mimarlık Fakültesi, Makine Bölümü, Tokat, Türkiye, (ORCID: 0000-0002-0780-893X). \\ (International Symposium on Multidisciplinary Studies and Innovative Technologies (ISMSIT) 2020 - 22-24 Ekim 2020)
}

(DOI: $10.31590 /$ ejosat.821620)

\begin{abstract}
ATIF/REFERENCE: Yaşar E. (2020). Bir Tartım Otomasyonunda, Platform Tipi Yük Hücrelerinin, S-tipi Olarak Kullanılması. Avrupa Bilim ve Teknoloji Dergisi, (Özel Sayı), 221-227.

Özet

Tarımsal ürünlerin dayanımını artırma gayretlerinden birisi de kurutmadır. Ürünlerin kuruma karakteristiklerini incelemek için yapılan çalışmalarda kütle oldukça önemlidir. Bu çalışmada, kurutma denemeleri için tasarlanmış 3 numune kabına sahip, sıcak hava ile çalışan bir deneysel kurutucu sisteme otomatik tartım sistemi yapılmıştır. Kurutma makinelerinde kapların ağırlıklarını ölçmek için operatör sürekli belirli zaman aralıklarında kapları yerinden çıkartarak, tartıp tekrar yerine koymaktadır. Kurutma süresi, ürün çeşidi ve miktarına göre 72 saate kadar sürebilmektedir. Bu çalışmada, ürünlerin kütle kaybını ölçmedeki zorluklara çözüm getirmek amacıyla bir tartım otomasyonu gerçekleştirilmiştir. Üç hazneli kurutucu için üç adet yük hücresi kullanılarak ürünlerin kütlesi istenen zaman aralıklarında anlık olarak ölçülmüştür. Bu çalışmada Arduino Mega, HX711 24 bit ADC kartı ve kullanıcı ile etkileşim bileşenlerine sahip Nextion ekran kullanılmıştır. Askı tip yükleri ölçmede sıklıkla kullanılan S-tipi yük hücreleri yerine çubuk şeklinde platform tipi yük hücreleri kullanılmıştır. Daha ucuz olan platform tipi yük hücreleri, hazırlanan aparatlarla S tipi yük hücresine dönüştürülmüştür. Bu sayede platform tipi yük hücrelerinden daha duyarlı ve ucuz birer S tipi yük hücreleri elde edilmiştir. Yapılan testlerde ölçmeye ait önemli parametreler elde edilerek sistemin başarımı kanıtlanmıştır.
\end{abstract}

Anahtar Kelimeler: Yük hücresi, Aduino Mega, Nextion ekran, HX711.

\section{The Use of Platform Type Load Cells as S-type in a Weighing Automation}

\begin{abstract}
One of the efforts to increase the strength of agricultural products is drying. Mass is very important in studies to examine the drying characteristics of products. In this study, an automatic weighing system was built on an experimental dryer system working with hot air with 3 sample containers designed for drying trials. In order to measure the weight of the containers in the drying machines, the operator removes the containers at certain time intervals, weighs them and puts them back into their place. Drying time takes up to 72 hours depending on the product type and quantity. In this study, a weighing automation was implemented in order to solve the difficulties in measuring the mass loss of products. By using a separate load cell for each container of the dryer, the mass of the test materials was measured instantaneously at the desired time intervals. In this study, Arduino Mega, HX711 24 bit ADC board and Nextion display with user interaction components are used. Instead of S-type load cells, which are frequently used to measure tensile forces, rod-shaped platform type load cells are used. The cheaper platform type load cells were transformed into $\mathrm{S}$ type load cells with the prepared apparatus. In this way, S-type load cells which are more sensitive and cheaper than platform type load cells were obtained. The performance of the system has been proven by obtaining important parameters of measurement in the tests.
\end{abstract}

Keywords: Load cell, Arduino Mega, Nextion display, HX711.

\footnotetext{
* Sorumlu Yazar: Tokat Gaziosmanpaşa Üniversitesi, Mühendislik ve Mimarlık Fakültesi, Makine Bölümü, Tokat, Türkiye, (ORCID: 0000-00020780-893X), ebubekir.yasar@gop.edu.tr
} 


\section{Giriş}

Yükün ölçülmesi, birçok endüstriyel ve ticari operasyonun en önemli bir parçasıdır. Üretim ve pazarlamada tekrar tekrar meydana gelen küçük hatalar önemli ölçüde gelir kaybına yol açabileceğinden, doğru yük ölçümlerine sahip olmak oldukça önemlidir(Anton Satria Prabuwono vd., 2009). Yük hücreleri, kuvveti elektrik sinyaline çevirerek ağırlık ölçmede sıklıkla kullanılır (Yunho Kim, Hyungchul Kim ve Junghoon Lee, 2009). Yük hücreleri yıllardır çeşitli uygulamalarda kullanılmaktadır ve genellikle endüstriyel ağırlıklandırma sistemleri için kuvvet sensörü olarak kabul edilmektedir (Jose S. Higino, Carlos Couto, 1995). Yük hücrelerinin yapısında daha çok esnemeyi algılayan gerinim ölçerler(strain gauge) kullanılmaktadır. Gerinim durumunda gerinim ölçerin direnç değeri değişir (Holman, 1995) (D. Leea vd., 2012). Gerilme durumunda direnç artarken, büzülme durumunda ise direnç azalmaktadır(dewesoft.com, 2020). Bu tip bir yük hücresinin performansı esnek elemana ve gerinim ölçerin özellikleri ile belirlenir (Yunho Kim, Hyungchul Kim ve Junghoon Lee, 2009). Çeşitli uygulamalar için gerinim ölçer teknolojisi kullanan çok sayıda yük hücresi geliştirilmiştir (Edmond Lou vd., 1988). Çoğu yük hücresi yüksek akım tüketimine, zayıf doğrusallığa ve düşük histeresize sahiptir(J. G. Webster, 1988). Gerinim ölçer yük hücreleri, endüstride ve araştırmalarda en yaygın olarak kullanılan hücrelerdir. Bu yük hücreleri özellikle serttir ve çok iyi rezonans değerlerine sahiptir bu yüzden uygulamada uzun ömürlü olma eğilimindedir. Gerinim ölçer yük hücrelerinin malzemesi uygun bir şekilde deforme olduğunda gerinim ölçerin deforme olması / gerilmesi / büzülmesi ilkesi üzerinde çalışır. Bu değerler son derece küçüktür ve malzeme yük hücresinin o sırada maruz kaldığı gerilim değeri ile ilişkilidir. Gerinim ölçer elemanının direncindeki değişiklik, elektriksel olarak ölçülebilir bir değer değişikliği sağlar. Direnç değişiminin potansiyel farka dönüştürülmesi amaciyla Wheatstone köprüsü denilen dirençlerden oluşan bir pasif devre kullanılır. Wheatstone köprüsü, basitlik, kullanılabilirlik ve güvenirlilik nedeniyle tercih edilir. Elektrik sinyali çıkışı tipik olarak birkaç mili volt düzeyindedir ve bir enstrümantasyon amplifikatörü tarafindan kullanılmadan önce yükseltilmesi gerekir. Dönüştürücünün çıkışı, dönüştürücüye uygulanan kuvveti hesaplamak için ölçeklendirilebilir (A. Qandil ve A. I. O. Zaid, 2015).

Yük hücreleri, uygun şekilde tasarlandığında ve kullanıldığında, çok doğru ve güvenilir sonuçlar veren sensörlerdir (Ivan Muller, 2010). Yüksek hassasiyete sahip yük hücreleri ise pahalıdır. Yük hücrelerinde ana esnek eleman genelde çelik ve alüminyum malzemeden oluşmaktadır. Esnekliği ise maksimum kapasiteyi belirler. Çözünürlüğü en yüksek esnek elemanlar çelik yapıya sahip olanlardır. Esnek metal malzemelerin ağırlık merkezleri etrafında oluşturulan büyük delikler malzemenin en fazla dayanabileceği yükü belirler.

Yük hücrelerinde frekans cevabı, eski konumuna gelebilme kabiliyeti ve histerezis eğrisi gibi parametreler yaygın hata kaynaklarındandır (D. Crescini, 2012).

Piyasada satılan üretilmiş yük hücrelerinden en duyarlı olanlarının başında çelik yapıda üretilmiş platform tipi yük hücreleri gelmektedir. Platform tipi yük hücrelerinin yapıları daha basit ve bu nedenle daha ucuzdurlar. Yapılarının basitliği bu tip yük hücrelerini geniş bir yelpazede üretilmelerini sağlamıştır. Birçok firmanın farklı kapasitelere sahip en geniş yük hücresi ailesi platform tipi yük hücreleridir. Ayrıca yük hücreleri içerisinde endüstriyel yapıda ve standartları karşılayan parametrelere sahip en küçük taksimatta(çözünürlük çıktısı), küçük kapasitelerde ağırlıklar için üretilmiş en fazla çeşide sahiptir. Platform tipi yük hücreleri küçük platform teraziler, hassas teraziler, tank-silo tartımlarında kullanılır. Diğer taraftan S-tipi yük hücreleri ise vinç basküllerinde, asma tip tank tartımlarında kullanılır. Birçok firmaya ait S tipi yük hücrelerinin kapasite değeri $25 \mathrm{~kg}$ dan başlamaktadır ve bundan daha düşük kapasitede S tipi yük hücresine sahip değillerdir.

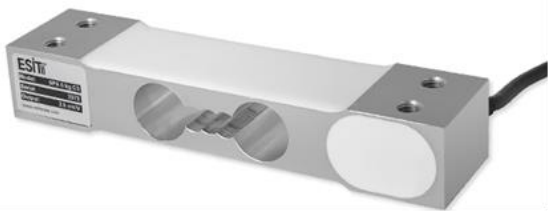

Şekil 1. A platform-type load cell

$\mathrm{Bu}$ daha düşük kapasiteli S-tipi yük hücresi üretilemez anlamına gelmemekle beraber istendiğinde özel üretim olarak üretilebilmektedir. Özel üretim yük hücreleri ise pahalı maliyete sahiptir.

$\mathrm{Bu}$ çalışmada sıcak hava ile kurutma yapan bir sisteme konulan malzemelerin ağırlık kayıplarını ölçen bir tartım otomasyonu yapılmıştır. Toplam 3 adet yük hücresinden alınan sinyaller sinyal iyileştirme devresinden ve ADC üzerinden Arduino Mega mikrodenetleyici karta uygulanarak veriler ekran üzerinde elde edilmişlerdir. Ayrıca Arduino Mega, seri port üzerinden elde ettiği verileri bilgisayara da istenirse gönderebilmektedir. Proje kapsamında Covid-19 kaynaklı bir zorunluluktan dolayı S tipi yük hücreleri yerine alınan platform tipi yük hücreleri askı tip uygulamada ağırlık ölçmek için kullanılmıştır. Dolayısı ile bu projede platform tipi yük hücreleri, S tipi yük hücreleri yerine kullanılmıştır.

\section{Materyal ve Metot}

\subsection{Yük Hücresi}

Yük hücreleri kuvveti elektrik sinyallerine çeviren sensörlerdir. Yüklerin ve kuvvetlerin ölçülmesi amacıyla kullanılır. Yük hücreleri, metallerin kuvvet uygulandığında esnemesi temelinde çalışır. Metallerdeki esneme miktarı gerinim ölçerler(strain-gauge) yardımıyla algılanarak elektriksel direnç değerine dönüştürülür. Bu projede ESIT marka SPA-3 model 3kg'lık platform tipi yük hücresi kullanılmıştır. SPA-3 model yük hücresi en fazla $3 \mathrm{~kg}$ ağırlık ölçebilen düşük çözünürlük değerine sahip bir yük hücresidir. Projede 
kullanılan platform tipi yük hücresi Şekil 1'de gösterilmiştir. Materyal olarak korozyona dayanıklı alüminyum metalden üretilmiştir. Yük hücresinin düşük skalada seçilmesi onun duyarlıllğını, pozitif etkileyecek bir parametredir. Sensör çözünürlüğü, sensörün girişinde meydana gelen ne kadarlık minimal bir değişimin sensör tarafından çıkış oluşturabilecek bir büyüklük olarak kabul edildiğini göstermektedir.

Genel olarak, yük hücresi Wheatstone köprü biçiminde dört gerinim ölçerden oluşur, ancak bir veya iki gerinim ölçerden oluşan çeşitleri de vardır. Elektriksel çıkış sinyali genellikle milivolt $(\mathrm{mV})$ olarak temsil edilir ve kullanılmadan önce mutlaka yükseltime gereksinimi vardır. Wheatstone köprüsüne ait şekil aşağıda gösterilmiştir (D. Atmajaya, 2018).

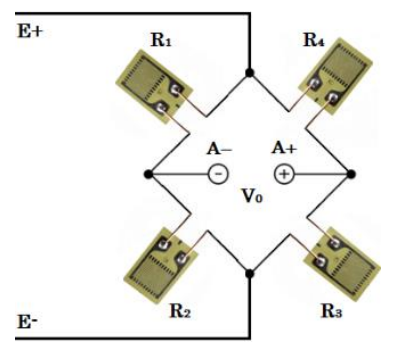

Şekil 2. HX711-Yük hücresi sensör bağlantısı

Wheatstone köprüsüne ait giriş ve çıkış gerilim ilişkisi Denklem I'de verilmişsir.

$$
V_{0}=\left[\frac{R_{3}}{R_{3}+R_{4}}-\frac{R_{2}}{R_{1}+R_{2}}\right] \cdot V_{E}
$$

\subsubsection{Băglantı Aparatları}

Projede S tipi yük hücrelerini, platform tipi hücrelerden elde etmek için her bir yük hücresi için iki adet $5 \mathrm{~mm}$ kalınlığında çelik levha CNC ile kestirilmiştir. Amaç yük hücresine asılan yükün iz düşümünü, yük hücresinin ortasından geçirmektir.
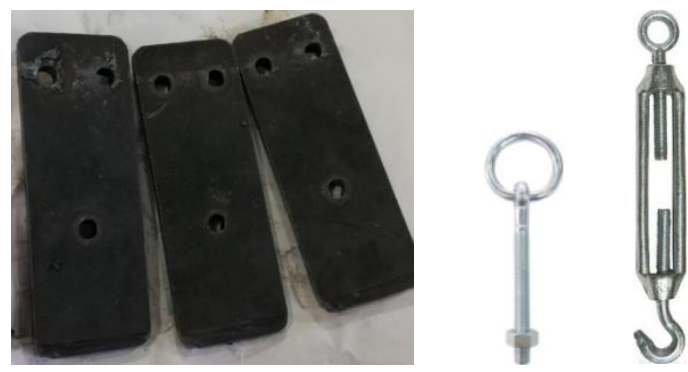

Şekil 3. A platform-type load cell

Her bir yük hücresi için bu levhalardan 2 adet kullanılarak platform tipi yük hücreleri S tipi yük hücrelerine dönüştürülmüştür. Ask1 için ise halkalı cıvata ve gerdirme mekanizması kullanılmıştır. Gerdirme mekanizması düşey mesafeyi ayarlamak için kullanılmıştır. Çünkü kurutma sistemindeki kapların kurutma kulelerine çok düşük mesafede yaklaşması gerekmektedir. S tipi şekline dönüştürülmüş bir yük hücresi aşağıda gösterilmiştir.

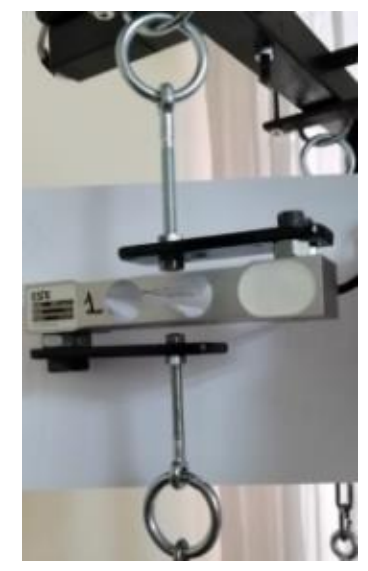

Şekil 4. Platform tipi yük hücresinden elde edilen S tipi yük hücresi

\subsection{Sinyal İyileştirme ve ADC(HX711)}

Yük hücreleri için kullanılan sinyal iyileştirme ve ADC ikisi bir arada son zamanların popüler çözümü HX711 modülü kullanılmıştır. Yapısındaki dahili sinyal kuvvetlendirici ve 24 bit çözünürlüğe sahip ADC modülü olan HX711, yük hücresi 
amplifikatörüdür. Dahili maksimum 128 kat kazanca sahiptir ve bu sayede küçük sinyalleri (mV) ölçebilir. HX711, kanal A ve kanal B olmak üzere iki kanala sahiptir ve iletişim süreci basittir. Örnekleme oranı nispeten <100 düşüktür (N. Ge ve L. Xie, 2019). HX711 sadece ADC içermemekte ayrıca yük hücresinden gelen (yük/ağırlık hücresi) sinyali filtreleme, yükseltme ve elde edilen verileri 2 hat(veri ve darbe sinyali) üzerinden mikrodenetleyiciye ileten bir karttır.

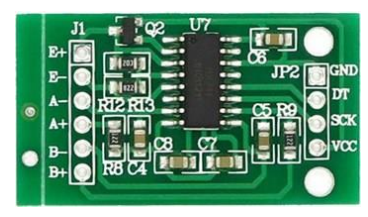

\section{Şekil 5. Sinyal kuvvetlendirici, ADC, filtreleme ve arayüz işlevlerini gören HX711 kartı}

Yük hücreleri için renk kodları üreticilere göre değişebilmektedir. Yük hücresi içerisinde bulunan Wheatstone köprüsü formasyonunda bağlanan dirençler Şekil 5'teki pin isimleri yardımıyla HX711'e bağlanarak kullanılır. HX711 içerisinde kullanılan ADC girişine uygulanan analog değer için $2^{24}=16.777 .216$ farklı değer üretebilir. $3 \mathrm{~kg}$ 'lık yük hücresinin çözünürlüğü $3000 / 16.777 .216$ $=0.00018 \mathrm{gr}$ okuma duyarlılı̆̆ına sahiptir. Sensör bu duyarlılıktan daha büyük(kaba) duyarlılığa sahip olduğundan seçilen ADC fazlası ile bu prosese yeterlidir.

Yük hücresini HX711'e bağladıktan sonra kart üzerindeki VDD, VCC, DAT, CLK ve GND bağlantıları mikrodenetleyiciye uygun olarak bağlanmıştır.

\subsection{Arduino Mega}

Gelen sinyalleri alıp, işlemek için yapısında mikrodenetleyiciye sahip programlanabilen Arduino Mega mikrodenetleyicisi kullanılmıştır. Arduino, yapısında mikroişlemci bulunan kullanışlı ve esnek bir açık kaynaklı elektronik prototip platformudur (D. Atmajaya, 2018). Arduino Mega 2560 mikrodenetleyici olarak 16 Mhz frekansa sahip Atmega2560 içeren bir karttır. 15 tanesi PWM özelliğe sahip 54 tane dijital giriş/çıkış pini vardır. Bunun yanında 16 tane analog giriş, 4 tane UART seri port vardır. Programlama hem USB üzerinden hemde ICSP konektörü üzerinden yapılabilmektedir. Ayrıca kartta reset tuşu bulundurmaktadır. Arduino kart aslında tam yeşekküllü Atmega2560 mikrodenetleyici için gerekli minimum konfigürasyona sahip bir karttır. USB üzerinden bilgisayar bağlantısı ile bir çok uygulama için hem kendi hemde çevre bileşenlerin güç gereksinimini karşılayabilmektedir. Arduino Mega istenirse pil ile veya harici adaptör ile de çalıştırılabilir.

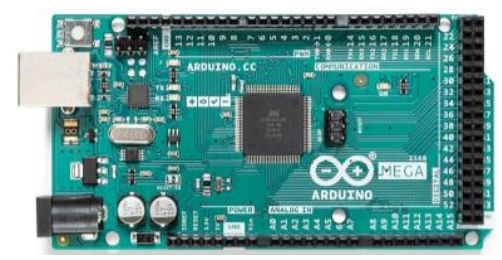

Şekil 1. Arduino Mega ve Pin yapısı

\subsection{Ekran Modülü}

Sistemin bilgisayar bağımlılığını ortadan kaldırmak ve çıktıları görebilmek için küçük bir ekran kullanılmıştır. Nextion ekran modülleri, hem kontrol amaçlı hemde ekran amaçlı LCD gibi modern yapıda arabirim olarak görev yapan benzersiz bir Human Machine Interface (HMI=Makine İnsan Arayüzü) çözümüdür. Nextion ekranı kullanım kolaylığı ve dokunmatik ekranından dolayı kullanıcı etkileşimi amacıyla seçilmiştir. Nextion, ürünü üreten firma olan ITEAD tarafından geliştirilen kendi editörü vardır, ITEAD Nextion ekran editörü, ekranları oluşturmak için kullanılır, cihazların kontrolüne izin verir, programların geliştirilmesi için bir yazılım olarak, nesneleri her nesnenin özelliklerinin ve öğelerinin konfigürasyonuna izin veren bir arayüze sahiptir (A. C. Bento, 2018). Bu açıdan geleneksel LCD ekranlardan daha farklıdır. Dokunmatik ekranı sayesinde dışarıdan komut alabilmektedir. Dahili kontrolcüsü sayesinde tek başına ekranlı bir bilgisayar gibi davranmaktadır. Bu ürünün kullanılması PC üzerinde çalışan ekran hazırlama programı ve donanım kısmında LCD ve dokunmatik panelden oluşmaktadır. Bilgisayara kurulan Nextion editörü ile ekran tasarımı yaparak(buton, etiket, grafik alanı, resim...) .tft uzantılı dosyayı SD karta yükleyip ekrana aktarılabilir. Ekran üzerinde bu amaçla SD kart yuvası bulunmaktadır. Bu sayede aynı tasarım ekranda yazılan kodlarla beraber çok kullanışlı bir HMI oluşturmaktadır. Nextion ekranlar arduino ile haberleşmek için yapısında bulunan seri portu(varsayılan baud oranı 9600 bps) kullanır. Bu durum uygulayıcıları kablolamanın zorluğundan kurtarır. Nextion ekranlarda program arayüzü hazırlamak için içerisinde birçok buton, metin kutusu, resim kutusu, gösterge paneli, zamanlayıcı... gibi araçlara sahiptir. Sürükle-bırak yöntemi ile ekranlar kolayca tasarlanarak tasarım sürecini önemli ölçüde azaltır.

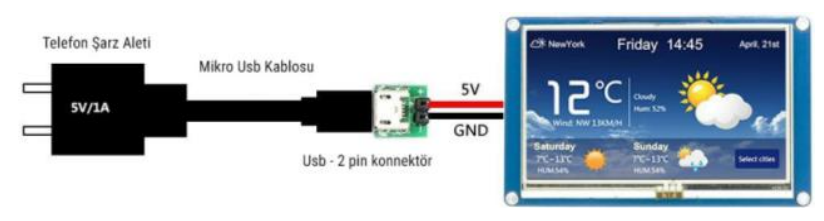

Şekil 2. Nextion HMI kartı 


\subsection{Ağırlık Ölçme Sistemi}

Yukarıda bahsedilen ağırlık ölçme sistemine ait bileşenler aşağıdaki blok diyagramda gösterildiği şekliyle gerçekleştirilmiştir. Yük hücresinden alınan sinyaller HX711 tarafından kuvvetlendirilerek ve sayısala çevrilere Arduino Mega'ya aktarılmaktadır. Arduino Mega gelen sinyali gr cinsinden kütle birimine çevirerekhem Nextion ekrana, hem de bilgisayara seri port üzerinden göndermektedir.

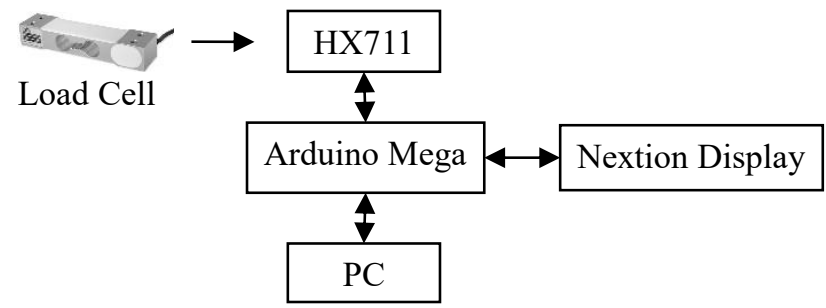

Şekil 8. Tartım otomasyonuna bileşenlerin bağlantısına ait blok şema

\subsection{Test ve Kalibrasyon Süreci}

Sistemin test ve kalibre edilmesi kurutucu üzerinde değil yük hücrelerinin üzerine bağlanacağı bir profilden yapılı platform üzerinde icra edilmiştir. Bu platforma ait resim Şekil 9'de gösterilmiştir. Sistemde kullanılan HX711 modülünün çıktısı ile gerçek gram değeri arasında bir dönüşüm oranının belirlenmesi çalışması kalibrasyon olarak adlandırılabilir. Bu değer Arduino long tipinde ve 12XX lü değerlerdir. Gramı bilinen ağırlıklar kullanılarak yapılan kalibrasyon değerleri programda kalıcı olarak saklanmaktadır.

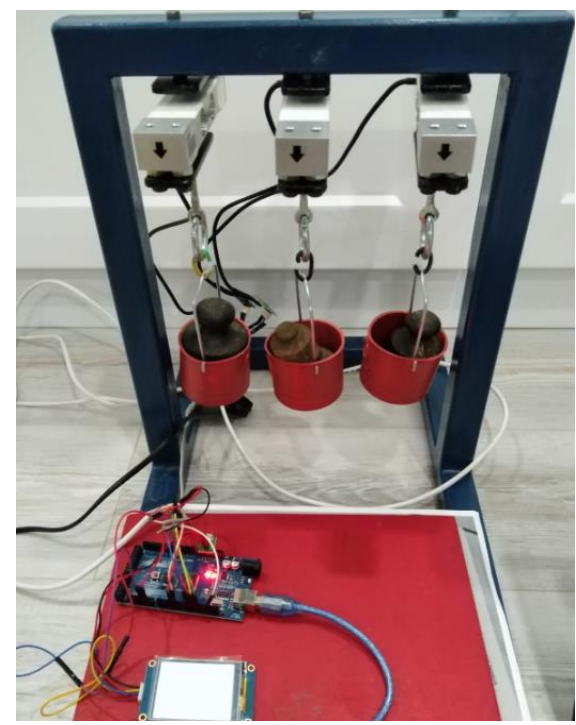

Şekil 3. Yük hücrelerinin bilinen ă̆ırlıklar kullanılarak kalibre edilmesi

Kalibrasyon için kullanılan kütleler 1gr-1000gr ağırlık arasında geniş bir skalaya sahip ağırlıkları bilinen kütlelerden oluşmaktadır. Sırasıyla 1, 2, 5, 10, 20, 50, 100, 250, 500, 1000 gr ağırlıklar kullanılmıştır. Ağırlıklara ait resim Şekil 10’da gösterilmiştir.

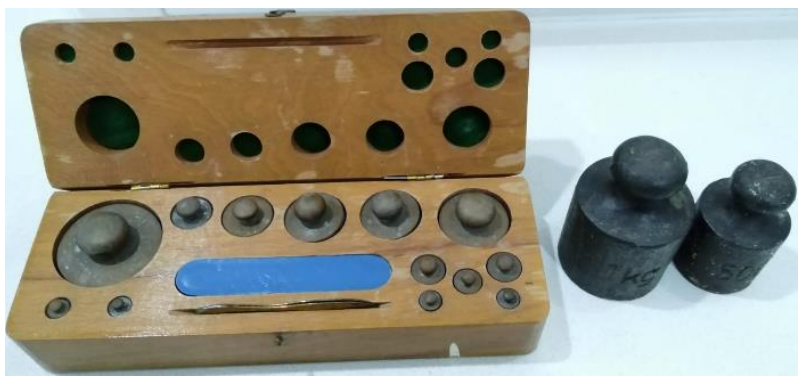

Şekil 4. Yük hücrelerinin kalibrasyonunda kullanılan kütleler

\subsection{Sistemin Montajı}

Ağırlık ölçüm sistemi, kurutucu üzerine profil demir iskelet yardımıyla sabitlenerek montaj edilmiştir. Kurutucuya ait numune kablarının tam izdüşümüne yük hücrelerinin yerleştirilmesi için hareketli bağlantı aparatı hazırlanmıştır. 


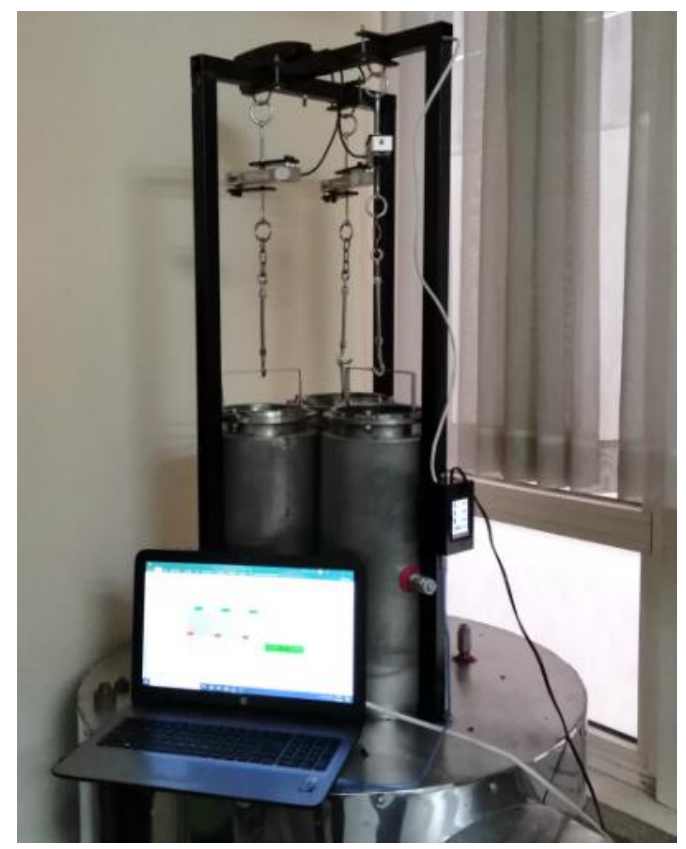

Şekil 5. Yük hücrelerinin kurutucu sistem üzerine bağlanması

Kabların yanında bilgisayar bağlantısı ve sensör değerlerinin okunması amacıyla Nextion ekran ve Arduino'nun bulunduğu kutu konulmuştur.

\subsection{PC yazılımı}

Kişisel bilgisayar üzerinde hazırlanan yazılım, veriler kaydedilmek isteniyorsa kullanılabilir. Bu amaçla bilgisayar üzerinde çalışacak bir yazılımda sisteme entegre edilmiştir. Yazılıma ait ekran görüntüsü aşağıda verilmiştir.

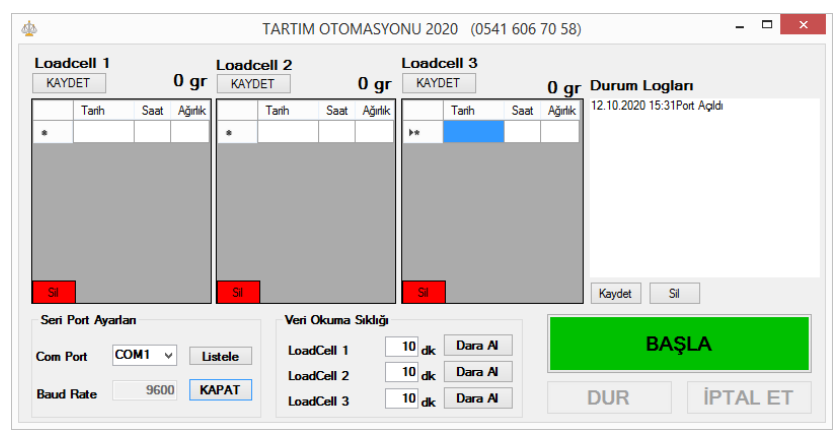

Şekil 12. Ağırlıkların ölçülmesi ve saklanması için hazırlanan program arayüzü

Bilgisayar yazılımı C\# programlama dili kullanılarak Windows platformuna uygun masaüstü uygulama şeklinde yazılmıştır. Program kurulum gerektirmeden tek bir uygulama dosyasina sahiptir.

Bilgisayar yazılımı verilerin .xls formatında saklanması amacıyla kullanılmışır. Verilerin izlenmesi ve ölçülmesi için bilgisayar bağlantısına gerek kalmadan Nextion ekran üzerinden Arduino yardımıyla ölçülen anlık veriler an be an takip edilebilmektedir. Bunun için sisteme harici bir adaptör ile elektrik bağlantısı sağlanmalıdır.

\section{Sonuç}

Kurutma sisteminde çalışılan numunelerin çalışma süresince istenen aralıklarda ağırlıklarının ölçülmesi ve kaydedilmesi projesine ait denemeler başarı ile gerçekleştirilmiştir. Elde edilen veriler .xls formatına çevrilerek Excel programının veriler üzerindeki gücünden faydalanılması amaçlanmıştır. Yük hücrelerinin istenen aralıklarda veri okuyabileceği ayarlar programa eklenmiştir. Program Arduino ile USB-Seri port dönüşümü ile haberleşmektedir. Sanal seri port ayarları ve seçimi programda kolayca yapılabilmektedir. Port durumlarına ait hata ve raporlamalar yine kayıt altına alınmaktadır.

Yapılan ölçümlerde herhangi bir hata ve problemle karşılaşılmamıştır. Kurutma sisteminde azda olsa oluşan titreşimlerin neden olduğu ağırlık değişimleri program üzerinden elimine edilerek hatalar giderilmiştir. Kurutma sistemindeki fan, ağırlıklarda bir miktar yanlış okumaya neden olmaktadır. Bu durumda okumadan önce fanın kapatılması ve sonra okuma yapması sağlanmıştır.

Elektrik kesintilerinde ve port bağlantı kayıplarında sistemin kaldığı yerden devam etmesi için gerekli yazılım eklemeleri yapılarak sistemin kullanışl1lı̆̆ artırılmıştır. 


\section{Teşekkür}

Bu çalışma Gaziosmanpaşa Üniversitesi Bilimsel Araştırma Projeleri Komisyonu tarafından desteklenmiştir. (Proje No: 2020/09).

\section{Kaynakça}

Anton Satria Prabuwono, Habibullah Akbar, Wendi Usino. (2009). International Conference on Computer Engineering and Technology. Yunho Kim, Hyungchul Kim ve Junghoon Lee. (2009). "Silicon-based capacitive load cell for tensile load measurement," Symposium on Design, Test, Integration \& Packaging of MEMS/MOEMS, Rome,pp. 410-415.

Jose S. Higino, Carlos Couto. (1995). Industrial Electronics, Control, and Instrumentation, Proceedings of the 1995 IEEE IECON 21st International Conference on. Volume: 2.

Holman. (1994). Experimental Methods for Engineers. Sixth Edition, McGraw-Hill publishers, New york.

D. Leea, H.P. Hongb, M.J. Leea, C.W. Park, N. K. Mina. (2012). A prototype high Sensitivity load cell using single walled carbon nanotube strain gauges, Sensors and Actuators A 180.

How to Measure Weight With Load Cell Sensors. (2020). Erişim adresi: https://dewesoft.com/daq/measure-weight-with-load-cellsensors\#what-is-load-cell.

Edmond Lou, V. James Raso, Nelson G. Durdle, ve Doug L. Hill. (1988). IEEE Transactions on Instrumentation and Measurement, VOL. 47, NO. 2, 1998.

J. G. Webster. (1988). Tactile Sensors for Robotics and Medicine, Wiley.

A. Qandil ve A. I. O. Zaid. (2015). "Considerations in the design and manufacturing of a load cell for measuring dynamic compressive loads," Power Generation System and Renewable Energy Technologies (PGSRET), Islamabad, pp. 1-6,

Ivan Muller, Renato Machado de Brito, Carlos Eduardo Pereira, ve Valner Brusamarello. (2010). Load Cells in Force Sensing Analysis - Theory and a Novel Application. IEEE Instrumentation \& Measurement Magazine.

D. Crescini. (2012). "Load cell for dynamic force measurements: An example in Thick-Film Technology," IEEE International Instrumentation and Measurement Technology Conference Proceedings, Graz, pp. 2448-2453.

D. Atmajaya, N. Kurniati, W. Astuti, Y. Salim ve A. Haris. (2018). "Digital Scales System on Non-Organic Waste Types Based on Load Cell and ESP32," 2018 2nd East Indonesia Conference on Computer and Information Technology (EIConCIT), Makassar, Indonesia, pp. 1-4, doi: 10.1109/EIConCIT.2018.8878667.

N. Ge ve L. Xie. (2019). "High Precision Weight Measurement of Liquid Viscosity," 2019 International Conference on Electronic Engineering and Informatics (EEI), Nanjing, China, pp. 269-276, doi: 10.1109/EEI48997.2019.00066.

A. C. Bento. (2018). "An Experiment with Arduino Uno and Tft Nextion for Internet of Things," International Conference on Recent Innovations in Electrical, Electronics \& Communication Engineering (ICRIEECE), Bhubaneswar, India, pp. 2138-2142, doi: 10.1109/ICRIEECE44171.2018.9008416. 